\title{
GLACIOCHEMICAL STUDIES AND ESTIMATED NET MASS BALANCES FOR RENNICK GLACIER AREA, ANTARCTICA
}

by

Boyd Allen III, Paul A. Mayewski*, W. Berry Lyons and Mary Jo Spencer

(Glacier Research Group, Department of Earth Sciences, University of New Hampshire, Durham, New Hampshire 03824, U.S.A.)

\section{ABSTRACT}

Two snow and ice cores from the Rennick Glacier area, Antarctica (study area center point lat $71^{\circ} 15^{\prime} \mathrm{S}$, long $\left.162^{\circ} 30^{\prime} \mathrm{E}\right)$ were analyzed for the chemical species: chloride, sodium, reactive silicate, sulfate and nitrate Core E10 $(6.35 \mathrm{~m})$ was taken from Evans Névé, a large accumulation basin at the head of Rennick Glacier. Core M1 $(4.35 \mathrm{~m})$ was extracted from the accumulation zone on the central plateau of the Morozumi Range, a small mountain massif bordering Rennick Glacier. Cores E10 and Ml span the time periods from 1929 to 1981 and from 1971 to 1981 , respectively, as dated using seasonal variations in chloride (E10) and sulfate (M1) concentrations. An estimated net balance of $50 \mathrm{~kg} \mathrm{~m}^{-2} \mathrm{a}^{-1}$ was derived for site E10 and of $182 \mathrm{~kg} \mathrm{~m}^{-2} \mathrm{a}^{-1}$ for site M1. The difference in net mass balance may be explained by elevational differences (M1 $1400 \mathrm{~m}$ a.s.l., E10 $2305 \mathrm{~m}$ a.s.1.). Recent (1973 to 1980) increases in sodium, silicate and sulfate at site E10 may be linked to decreases in Antarctic pack-ice extent (Kukla and Gavin 1981) for the same period.

\section{INTRODUCTION AND BACKGROUND}

The Antarctic ice sheet is considered to be one of the important driving forces behind global and atmospheric circulation (Weyant 1967). Consequently, any changes in the size of the ice masses comprising this ice sheet may have a serious influence on the Earth's weather. North Victoria Land comprises the northernmost East Antarctic sector of the Transantarctic Mountains (Fig.1). It is bordered by the polar plateau on the south and west, the Ross Sea and Ross Ice Shelf to the east and by the Pacific Ocean to the north. Rennick Glacier, discovered during the 1959-60 traverse of north Victoria Land (Stuart and Heine 1961), is one of the more prominent physiographic features. It flows northward for approximately $400 \mathrm{~km}$, attaining maximum width of approximately $60 \mathrm{~km}$ and flows past several localized accumulation areas including the Morozumi Range.

The only meteorological data collected from a station located in this region are from Hallett station (Fig.1). For the period from 1957 to 1972 the mean annual temperature was $-15.3^{\circ} \mathrm{C}$ and the mean summer temperature was $-1.6^{\circ} \mathrm{C}$ (Duphorn 1981). Mean annual surface temperature for the upper Rennick Glacier area is estimated to be approximately $-20.5^{\circ} \mathrm{C}$, based on mean monthly surface temperatures (US Navy 1981). Close to Litell Rocks (680 m a.s.l., Fig.1) a constant temperature of $-16.5^{\circ} \mathrm{C}$ at 10 to $18 \mathrm{~m}$ depth was recorded and is interpreted as the mean annual temperature for the site.

Snow, snow pellets, snow grains and ice crystals are the predominant forms of precipitation in north Victoria Land and rain was reported along the coast of Robertson

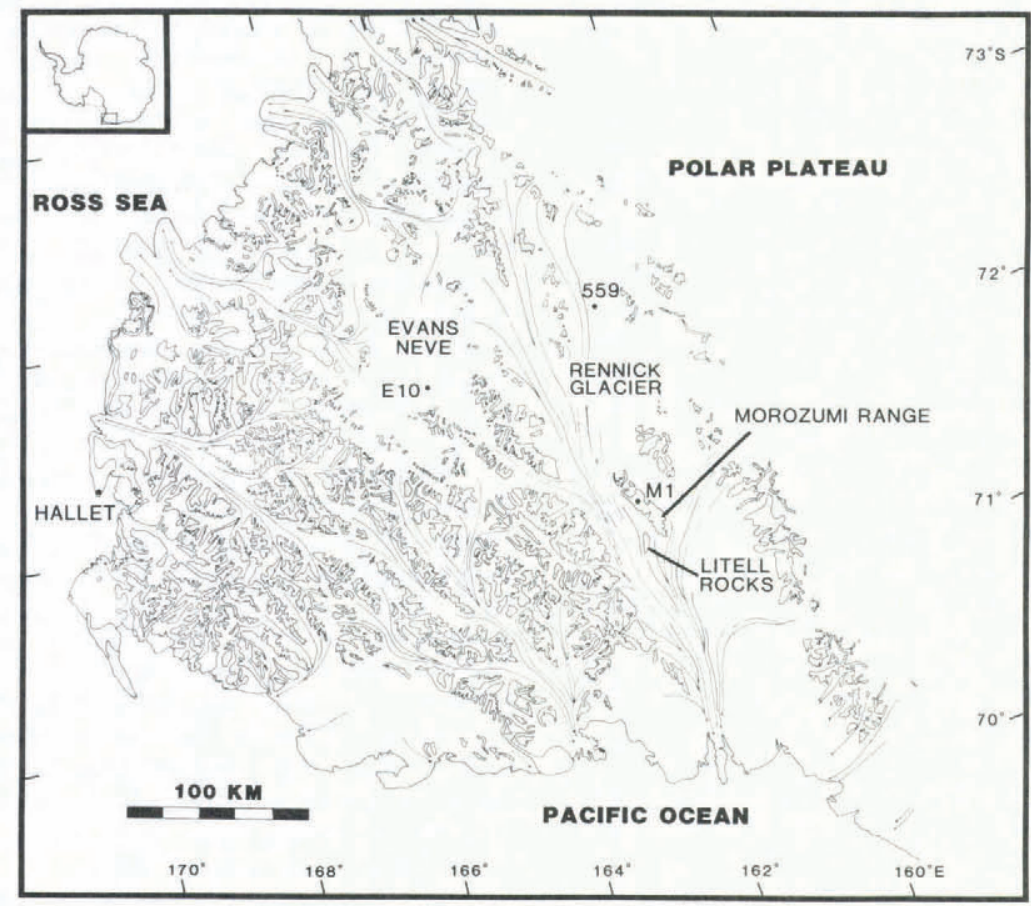

Fig.1. Map of north Victoria Land (after USGS north Victoria Land 1:500 000 map, 1965). Outlined areas represent areas of exposed bedrock or thin ice cover. Arrows represent glacier flow lines.

\footnotetext{
* Correspondence should be addressed to this author.
} 
Bay twice in January during the 1979-80 German Northern Victoria Land Expedition (GANOVEX) (Duphorn 1981). Annual snowfall at Hallett averages about $183 \mathrm{~kg} \mathrm{~m}^{-2} \mathrm{a}^{-1}$ with the maximum monthly snowfall in March and the minimum in November (Duphorn 1981). Glaciochemical methods have been used successfully for dating purposes in other sections of Antarctica (Herron 1982[a]), notably the Ross Ice Shelf, East Antarctica (Delmas and Boutron 1980) and the Antarctic Peninsula (Aristarain and others 1982). As such, they were employed in this study in order to estimate the net mass balance and sources of moisture feeding the Rennick Glacier region for purposes of glaciological reconstruction, and as a test of whether or not this technique is feasible in such an area. The only other recorded net mass balance measurement for this region is $163 \mathrm{~kg} \mathrm{~m}^{-2} \mathrm{a}^{-1}$ (Stuart and Heine 1961) at snowpit 559 (Fig.1).

\section{METHODOLOGY}

In order to assess the net balance and determine sources for air masses entering the study region two coring sites were chosen. Site E10, $2305 \mathrm{~m}$ a.s.l., is in Evans Névé and site M1, $1400 \mathrm{~m}$ a.s.l., is in the Morozumi Range. The E10 site provides information concerning the accumulation feeding Rennick Glacier. The Ml site, a localized accumulation basin closer to the coast than E10, provides both a coastal comparison and a site from which to determine net mass balance and moisture sources for alpine glaciers flanking the Morozumi Range.

Methodology employed in this study is made up of five phases: recovery, transport, sectioning, analysis, and data reduction. All acrylic plastic cutters and scrapers used in this study, and the polystyrene jars used for sample storage, were triple-washed in Milli- $\mathrm{Q}^{\mathrm{TM}}$ water $(17.9 \mathrm{M} \Omega \mathrm{cm})$.

Cores measuring 6.35 and $4.65 \mathrm{~m}$ at sites E10 and M1, respectively, were recovered using a SIPRE teflon-coated auger. Sites were approached from downwind. All personnel involved with recovery wore plastic gloves and particle masks, and workers involved with packaging of the core wore plastic suits as well. Once removed from the auger barrel, cores were placed on a Saran Wrap ${ }^{\text {TM }}$-covered work area, measured, described, scraped with plastic scrapers, and triple-bagged in particle-free bags. The cores were shipped frozen to the University of New Hampshire and stored at $-15^{\circ} \mathrm{C}$. Sectioning of the cores was performed in a cold room $\left(-4^{\circ} \mathrm{C}\right)$. A sampling interval of $0.04 \mathrm{~m}$ was selected wherever possible in order to provide subseasonal resolution of ion concentrations based on an estimated snow-accumulation rate for the study area of $163 \mathrm{~kg} \mathrm{~m}^{-2} \mathrm{a}^{-1}$ (Stuart and Heine 1961); however, breakage of the core during extraction did not always permit this interval. After sectioning with plastic cutters, densities were determined and the outer surfaces of the sections were removed by scraping. The sections were then put into polystyrene jars and stored in a freezer. Approximately $10 \mathrm{ml}$ water equivalent was sectioned off each frozen sample and placed in a separate jar to be analyzed later by ion chromatography. The remaining samples were thawed and acidified with Ultr
ultrapure nitric acid to approximately $1 \%$ by volume.

Sodium was analyzed by flame atomic absorption spectrometry using a Perkin-Elmer model 2280 instrument. Cesium chloride (ACS grade) solution was added to a final concentration of $2 \%$ in order to control ionization. Reactive silicate was determined colorimetrically using a Technicon AutoAnalyzer $\mathrm{II}^{\mathrm{TM}}$ (Glibert and Loder 1977). Sample containers were kept closed to minimize room contamination. Repeated blank studies determined room contributions to be less than $0.01 \mu \mathrm{mol} 1^{-1}$ for sodium and silicate.

Chloride, sulfate and nitrate were determined simultaneously on a Dionex 10 ion chromatograph using a fast-run anion separation column, an eluent consisting of $0.003 \mathrm{~mol} \mathrm{NaHCO}_{3}$ and $0.002 \mathrm{~mol} \mathrm{Na}_{2} \mathrm{CO}_{3}$ and a $0.3 \mu \mathrm{S}$ full-scale chart recorder setting. Three aliquots for each sample were injected with a gas-tight syringe (Hamilton) into a $1 \mathrm{ml}$ sample loop. The ion chromatography was performed in a class 100 clean laboratory at the Mellon Institute, Pittsburgh, Pennsylvania.

Standard deviations in $\mu \mathrm{mol} 1^{-1}$ for the analyses were: chloride 0.63 , sodium 0.09 , silicate 0.03 , sulfate 0.04 , and nitrate 0.01 . Container blanks were created by filling polystyrene jars with Milli- $\mathrm{Q}^{\mathrm{TM}}$ water $(17.9 \mathrm{M} \Omega \mathrm{cm})$ at the time of core-sectioning. These jars were placed in the same freezer as the samples and they underwent identical handling and analytical procedures. Mean blank concentrations in $\mu \mathrm{mol} 1^{-1}$ were: chloride 1.08 , sodium 0.13 , silicate 0.04 , sulfate 0.06 , and nitrate 0.01 . The high chloride blank is attributed to contamination by organic solvents during storage in Pittsburgh. Aristarain and others (1982) encountered similarly high chloride blanks and assumed there was organic solvent contamination of plastic vials.

Statistical analyses included spectral and cross-spectral analysis of the time series produced from each core, factor analysis and production of a correlation coefficient matrix. All statistical manipulations and tests were performed on a DEC-10 computer.

By using time-series analysis, a mathematical transformation is made on the chemical data sets to expose characteristic variations that might normally be masked by seasonal or other oscillatory effects. This technique has been used before on other glaciochemical data (Mayewski and others 1984). A regularly spaced data set (every $0.04 \mathrm{~m}$ downcore) for the chemical species and density was constructed from the E10 and Ml analytical results and examined using a time-series program in the International Mathematical and Statistical Libraries (Release 9.1, IMSL Inc 1982) statistical package. The $0.04 \mathrm{~m}$ interval satisfies the Nyquist sampling theorem (Kelley 1976) for what was assumed to be a good estimate of the net mass balance for the region, $163 \mathrm{~kg} \mathrm{~m}^{-2} \mathrm{a}^{-1}$ (Stuart and Heine 1961).

To determine the periodicity for each chemical species downcore, spectral density (power) was computed using a spectral analysis program in the IMSL package. (Power is the measure of how much of the variance exists at a particular frequency (Mayewski and others 1984).) Peaks in the power spectrum were used in the manual selection of maximum concentration peaks to be used as seasonal indicators.

Cross-spectral analysis was used to identify similar periodicities of different chemical species. The squared coherence in cross-spectral analysis is the proportional amount of spectral density in signal two (e.g. sodium concentrations) that could be predicted by signal one (e.g. chloride concentrations) using a linear regression that is frequency-dependent (Koopmans 1974). Thus, coherence is a measure of the extent to which one time series is similar in trend to another and is analogous to a correlation coefficient. The phase at a particular frequency is the amount that one component leads another as a Fourier representation of the time series (Koopmans 1974). Confidence intervals for power peaks and coherence were selected using tables in Koopmans (1974) and Arkin (1962).

Principal component analysis using the Statistical Package for the Social Sciences (Release 7-9, SPSS Inc 1981) was then used to evaluate the variance in chemical concentrations for each core. Principal component analysis has been used on other glaciochemical data from Antarctica (Boutron and Martin 1980) and is a form of factor analysis which characterizes the variance between measured variables by generating mathematical components or factors common to all of the variables (Lewis and others 1983). The communality is the measure of the total variance explained by the factors. These factors are then intuitively related to physical processes or components (Van Epsen and Adams 1983).

Correlation coefficients which measure the linear relationships between two variables have also been used previously on Antarctic glaciochemical data (Boutron and Martin 1980) and were obtained using the SPSS factor analysis program.

For estimation of annual net mass balances, the cores are dated using seasonal concentration peaks. Because of the much lower precision in the density determination ( 8 

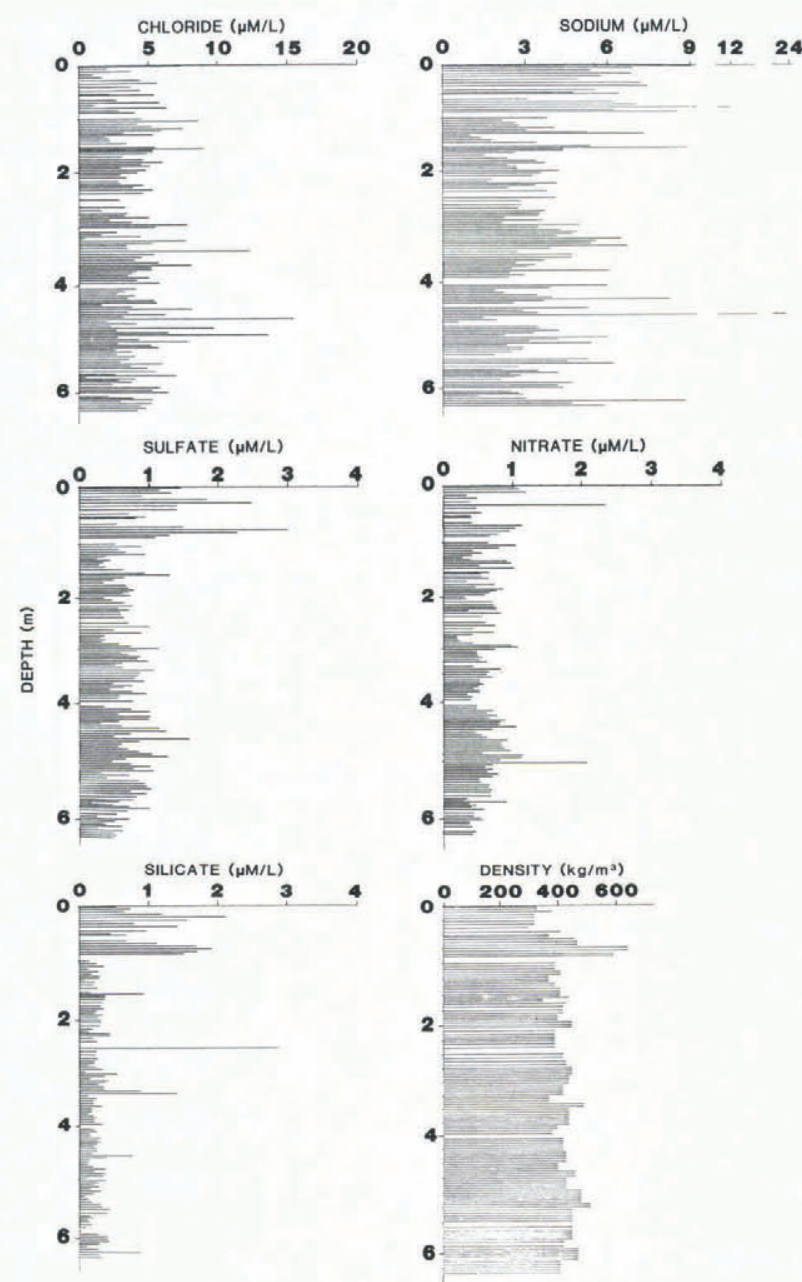

Fig.2(a). Chemical and density data for core from site E10.

to $16 \%$ ) as compared to the chemical analyses, individual sections of the core are not density-normalized, thus avoiding the introduction of additional error. Individual density values within each annual section of core are averaged and then multiplied by that core-section length to arrive at an adjusted water equivalent net mass balance. As the time-series analysis was used only as an aid in the manual selection of concentration peaks, and in view of the low precision and relative similarity in density downcore (Figs.2(a) and (b)), the data set for the statistical analyses was also not density-normalized for individual sections of the cores.

\section{RESULTS AND DISCUSSION}

Analytical results (concentration in $\mu \mathrm{mol} \mathbf{1}^{-1}$ ) are presented in Table I and possible source types of the
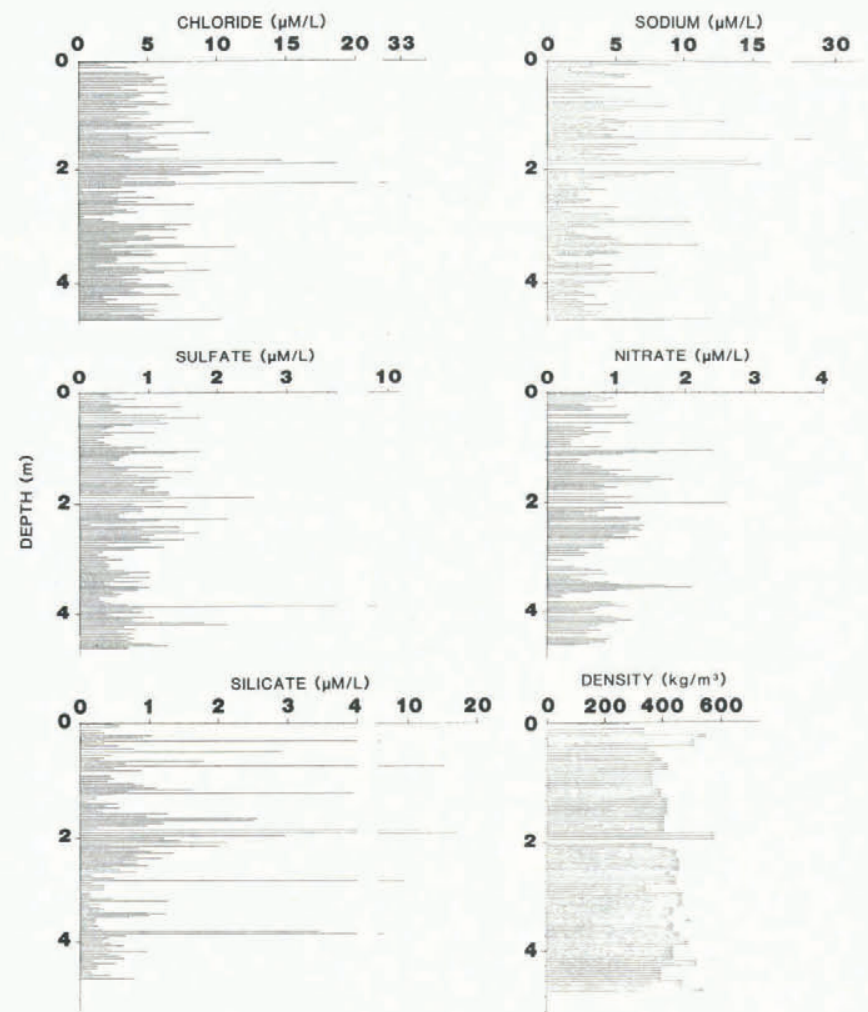

DENSITY $\left(\mathrm{kg} / \mathrm{m}^{3}\right)$

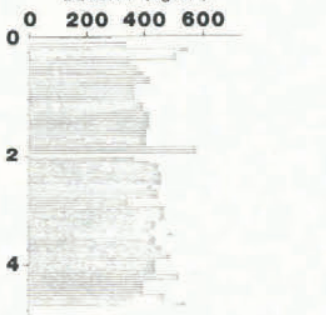

Fig.2(b). Chemical and density data for core from site M1.

chemical species examined in this study are discussed. Results from the statistical analyses are interpreted and the annual net mass balances estimated. Possible explanations for the observed chemical trends are then offered. To offset the large influence of the higher concentration spikes observed in some samples (Figs.2(a) and (b)) the median concentration for each chemical species was determined (Table I).

The chemical species analyzed come from a variety of sources including marine, crustal, volcanic, anthropogenic, and cosmogenic. Source discrimination is based largely on previous Antarctic glaciochemical work. For coastal Antarctic areas such as north Victoria Land, the main source of chloride is probably from marine salt particles but some gas-derived chloride in excess of the marine ratio may be possible (Delmas and others 1982). Contributions from volcanic activity (Herron 1982[b]) or weathering of chloride salts (Dow and Neall 1974) is also possible.

Sodium, like chloride, has a marine source and minor contributions can be derived from weathered crustal materials, as observed on the Antarctic Peninsula (Aristarain and others 1982). In north Victoria Land, proximity of the core sites to the coast suggests a marine

TABLE I. MEDIAN CONCENTRATION OF CHEMICAL SPECIES ( $\left.\mu \mathrm{mol} 1^{-1}\right)$ IN CORES FROM SITES E10 AND M1

E10

Chloride

$4.15(n=138)$

Sodium

$3.55(n=136)$

Silicate

$0.28(\mathrm{n}=141)$

Sulfate

$0.71(n=140)$

$0.60(n=136)$
Ml

$4.60(n=124)$

$3.81(n=118)$

$0.49(\mathrm{n}=125)$

$0.76(n=126)$

$0.82(n=111)$
Upper E10*

$3.78(n=19)$

Lower E10**

$6.44(\mathrm{n}=19)$

$3.39(n=117)$

$1.12(\mathrm{n}=19)$

$0.26(n=122)$

$1.32(\mathrm{n}=19)$

$0.67(n=121)$

$0.64(\mathrm{n}=19)$

$0.59(n=117)$

* Top meter of core E10.

** Remaining length of core E10. 
source for sodium, but rock exposure in the surrounding region (Fig.1), particularly at the southern end of the Morozumi Range, could provide a crustal source. Silicate is derived primarily from crustal weathering products (Mayewski and Lyons 1982) such as the extremely weathered Beacon Supergroup which comprises more than $50 \%$ of the Morozumi Range and is found in the ice-free areas around the core sites.

Sources for sulfate in Antarctica include volcanic activity, sea-salt injection and anthropogenic input (Herron 1982[b]), oxidation of marine gaseous compounds (Delmas and others 1982), and input of weathered salts (Dow and Neall 1974). Based on work at South Pole station by Delmas and Boutron (1980), anthropogenic input of sulfate to Antarctica is considered to be minimal. Delmas and others (1982) postulate a predominantly long-range, atmospherically transported aerosol source for sulfate. Mt Erebus on Ross Island continually emits a sulfate-rich plume (Radke 1982) and storm tracks (Dort 1968) could transport aerosol here to north Victoria Land. Thus, the main source of sulfate to the coring sites is probably long-range transport supplemented by volcanic emission.

Marine, volcanic, anthropogenic and cosmogenic sources have all been suggested as potential sources for nitrate in Antarctica (Zeller and Parker 1981). These multiple sources of nitrate make it difficult to identify any principal origin, although Delmas and others (1982) consider most Antarctic nitrate to be from a distant source and to have undergone long-range, atmospheric transport.

Because multiple sources exist for several of the chemical species, correlation and factor analysis results (Table II) are used to suggest common input mechanisms for these species. In the E10 core significant correlation exists between the following species: chloride-sodium, sodium-silicate, sodium-sulfate, silicate-sulfate, and sulfate-nitrate. Factor analysis of E10 yielded two factors with factor 1 being interpreted as a crustal source because of the high factor loadings of sodium and silicate and their significant correlation with each other. High loading of chloride and sodium on factor 2 suggests a marine input mechanism. The even split of sulfate between factors 1 and 2 may be explained by some sulfate arriving with marine salts and the remainder mixing in with crustal weathering products transported to the core site. The low nitrate variance explained by the factor analysis for E10 verifies the likelihood of either multiple sources or a unique origin of nitrate unrelated to the other chemical species.

In the M1 core significant correlation (99\%) exists only between sodium-silicate and sulfate-nitrate. The presence of sodium and chloride in factor 1 and correlation of sodium with silicate suggests that marine input could be related to crustal input. This might be caused by intermixing of marine salts with crustal weathering products. Since the input of crustal weathering products to the core site is believed to be continuous, the association between these species might be used to suggest that marine salts are supplied to the site throughout most of the year. Loading of most of the sulfate and nitrate and half of the chloride on factor 2 implies a common source for these species which may be in the form of long-travelled gas-derived aerosols as observed at South Pole station (Delmas and others 1982).

At site E10 only chloride and sodium display any spectral power and only at an interval of $0.13 \mathrm{~m}$. Cross-spectral analysis indicates that these two species occur in phase. The cyclical variations in chloride and sodium input are believed to be annual, because their marine source is modulated by the annual changes in sea ice. This idea is reinforced by Herron's (1982[a]) documentation of their seasonal occurrence in samples from Ross Ice Shelf. The high chloride concentration peaks (Fig.2(a)) were selected as annual markers because more chloride data were available than sodium data. This results in a record from 1929 to 1980 (Fig.3) with an estimated mean annual net mass balance of $50 \pm 2 \mathrm{~kg} \mathrm{~m}^{-2} \mathrm{a}^{-1}$. Because error is estimated at $\pm 0.02 \mathrm{~m}$ for each seasonal concentration maximum based on the
TABLE II, RESULTS OF FACTOR ANALYSIS FOR CORES FROM SITES E1O AND MI

E10

Factor loading

$\begin{array}{lccc} & \begin{array}{c}\text { Factor } \\ 1\end{array} & \begin{array}{c}\text { Factor } \\ 2\end{array} & \text { Communality } \\ \text { Chloride } & -0.25 & 0.65 & 0.484 \\ \text { Sodium } & 0.30 & 0.67 & 0.532 \\ \text { Silicate } & 0.84 & 0.17 & 0.742 \\ \text { Sulfate } & 0.53 & 0.50 & 0.537 \\ \text { Nitrate } & 0.10 & 0.26 & 0.076 \\ \text { \% variance } & 71.3 & 28.7 & \end{array}$

M1

Factor loading

$\begin{array}{lccc} & \begin{array}{c}\text { Factor } \\ 1\end{array} & \begin{array}{c}\text { Factor } \\ 2\end{array} & \text { Communality } \\ \text { Chloride } & 0.35 & 0.30 & 0.214 \\ \text { Sodium } & 0.53 & 0.07 & 0.289 \\ \text { Silicate } & 0.83 & 0.08 & 0.689 \\ \text { Sulfate } & 0.24 & 0.67 & 0.511 \\ \text { Nitrate } & -0.01 & 0.62 & 0.385 \\ \text { \% variance } & 75.6 & 24.4 & \end{array}$

$0.04 \mathrm{~m}$ sampling interval, and since two seasonal maxima are involved for dating purposes, error for each annual determination is calculated as $\pm 0.04 \mathrm{~m}$ or $30 \%$.

At site M1 only sulfate and nitrate exhibit spectral power and only at the $0.40 \mathrm{~m}$ interval. A simultaneous input is suggested by the cross-spectral analysis and simultaneous input of sulfate and nitrate concentrations has been statistically demonstrated in samples from Vostok (Kyle and others 1982). Herron (1982[a]) found seasonal variations for sulfate and nitrate on Ross Ice Shelf and considered that both species had summer maxima. Thus, the sulfate and nitrate are thought to be indicative of summer input to north Victoria Land. Sulfate was selected over nitrate as a seasonal indicator for the Ml core because the data set was more complete (Fig.2(b)), providing an Ml record that extends from 1971 to 1980 (Fig.3) with an estimated mean annual net mass balance of $182 \pm 2 \mathrm{~kg} \mathrm{~m}^{-2} \mathrm{a}^{-1}$. Error is assumed to be only

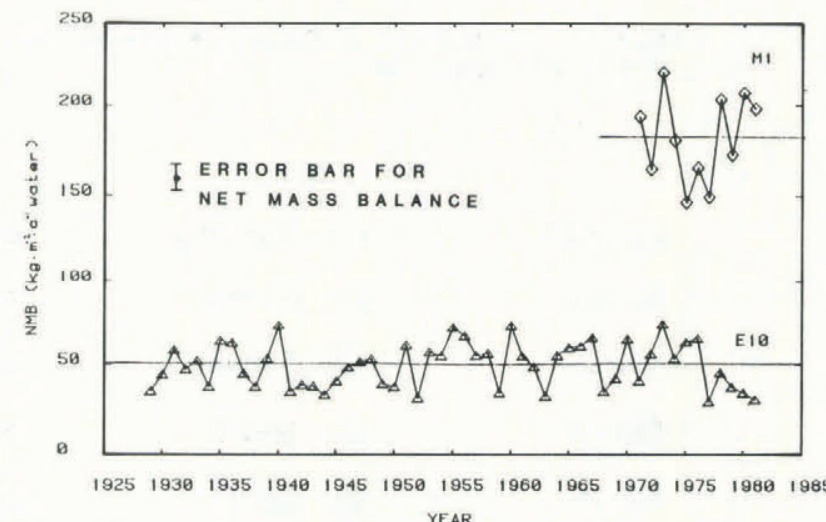

Fig.3. Annual net mass balances $\left(\mathrm{kg} \mathrm{m}^{-2} \mathrm{a}^{-1}\right)$ for site $\mathrm{E} 10$ (triangle) and site Ml (diamond). Horizontal line signifies mean value. 
$10 \%$ at $\mathrm{Ml}$ because of the larger accumulation rate at M1 compared to E10. The Ml estimated mean annual net mass balance is similar to the $163 \mathrm{~kg} \mathrm{~m}^{-2} \mathrm{a}^{-1}$ obtained by Stuart and Heine (1961) at snowpit 559 (Fig.1), using snow stratigraphy based on identification of five annual layers.

The lower seasonal resolution in the E10 core resulted from using a sampling scheme based on the only estimate of net mass balance for the region which was three times larger. The variation in estimated annual net mass balances might be a function of elevation (M1: $1400 \mathrm{~m}$, snowpit 559: $1720 \mathrm{~m}$, E10: $2305 \mathrm{~m}$ a.s.1.) or the amount of precipitation reaching each location.

A comparison between the two sites in north Victoria Land is only possible for the period between 1971 and 1980 (Fig.3). Although similarities between the relative pattern of increasing and decreasing net balance at both sites appear in Figure 3, there is no statistically significant correlation $(r=0.035)$ between annual net mass balances at each site. Mean chemical concentrations were calculated for each net mass balance year and there was no significant correlation $(95 \%)$ between annual concentrations for species within each core $(r=0.001-0.103)$ or $f$ or individual species between the two cores $(r=0.002-0.152)$.

Short-term changes in the spatial variability of chemical concentrations can be evaluated by examining the upper meter of E10 (1973-80) and the entire M1 core (1971-80). Long-term changes are observed by comparing the upper meter of E10 (1973-80) with the remainder of the E10 core record (1929-72).

The upper meter of E10 compared to Ml has higher concentrations ( \pm 1 standard deviation) of sodium, silicate and sulfate, similar chloride and lower nitrate concentrations. The chloride concentrations are similar within the relatively large standard error $\left(0.63 \mu \mathrm{mol} 1^{-1}\right)$ and better precision might have yielded an expected higher chloride value at M1, due to its more coastal location. The large sodium, silicate and sulfate inputs are visible in the upper meter of E10 (Fig.2(a)) and might reflect a source unique to the ElO site that has become available during the period 1971-80. Comparison of the upper meter of E10 (1971-80) with the remainder of the core (1929-72) shows increased sodium, silicate and sulfate, and similar chloride and nitrate, concentrations ( \pm 1 standard deviation.)

Crustal weathering would be a source type common to the three increased chemical species and the higher concentrations might be explained by increases in ice-free areas or changes in atmospheric circulation patterns. One possible driving mechanism for these changes is areal changes in Antarctic pack ice. Using remote sensing data, Kukla and Gavin (1981) note a $2.5 \times 10^{6} \mathrm{~km}^{2}$ decrease (from 8.2 to $5.7 \times 10^{6} \mathrm{~km}^{2}$ ) in the areal extent of summer pack ice surrounding Antarctica during the period from 1973 to 1980 (the same period of time represented by the upper meter of E10). The same process decreasing the areal extent of sea ice might also be increasing the area of ice-free exposure surrounding the E10 site which would explain the additional crustal input. These dynamic changes in sea-ice extent may not necessarily yield an increase in chloride concentrations but might promote changes in ice-free areas that would be less seasonally dynamic and generate a greater abundance of crustally weathered material. Volcanic material may have contributed a portion of the higher concentrations observed.

Differences in concentrations between the E10 and MI cores become greater if there is a dilution effect for wet deposition as a function of the snow-accumulation rate (Herron 1982[a]). Silicate is assumed to be derived solely from crustal weathering (Mayewski and Lyons 1983) and would be input as dry deposition. But the multiplicity of sources for the other chemical species makes it difficult to estimate the percentages of wet and dry deposition. Since the distinction between wet and dry deposited concentrations is beyond the scope of this study, a worst case is assumed and median concentration values $\left(\mu \mathrm{mol} \mathrm{a}^{-1}\right)$ are weighted for annual net mass balance (Table III).
TABLE III. DILUTION-ADJUSTED MEDIAN CONCENTRATIONS $\left(\mu \mathrm{mol} \mathrm{a}^{-1}\right)$ IN CORES FROM SITES E10 AND M1.

\section{E10 M1 Upper E10* Lower E10**}

$\begin{array}{lrrrr}\text { Chloride } & 3.07 & 12.11 & 3.16 & 3.11 \\ \text { Sodium } & 2.63 & 10.03 & 5.39 & 2.51 \\ \text { Sulfate } & 0.53 & 2.00 & 1.10 & 0.50 \\ \text { Nitrate } & 0.44 & 2.16 & 0.54 & 0.44 \\ \text { Silicate } & 0.21 & 1.29 & 0.94 & 0.19\end{array}$

* Top meter of core E10.

** Remaining length of core E10.

In this worst case the M1 core has greater concentrations for all species compared to E10. It is likely that this greater annual input to $\mathrm{Ml}$ is attributable to its more coastal location. The actual answer may lie somewhere between these two extremes and more investigation is necessary to understand the differences in concentrations between the two sites.

\section{SUMMARY}

Glaciochemistry has been used at two sites in north Victoria Land to estimate annual net mass balance and to identify source areas for several chemical species. The conclusions are as follows.

(1) There is no apparent trend in fluctuations of annual net mass balance at both sites for the study periods from 1929 to 1980 at E10 and from 1971 to 1980 at Ml, but the estimated mean annual net mass balance at M1 $\left(182 \pm 2 \mathrm{~kg} \mathrm{~m}^{-2} \mathrm{a}^{-1}\right)$ is about three times that of E10 $\left(50 \pm 2 \mathrm{~kg} \mathrm{~m}^{-2} \mathrm{a}^{-1}\right)$. This difference might be explained by the lower elevation of $\mathrm{Ml}(1400 \mathrm{~m}$ a.s.l.) relative to E10 (2305 m a.s.1.).

(2) Sodium and chloride are probably derived from marine sources and are believed to be seasonally modulated at site E10 but show no periodicity at site M1. Some sodium may be of crustal origin.

(3) Silicate is locally derived from ice-free areas and shows no periodicity at sites E10 and M1. Silicate and crustally derived sodium concentrations have increased in recent times (1973-80) at E10. This is probably due to increased exposure of ice-free areas.

(4) Sulfate and nitrate probably came from Mt Erebus and from distant sources. These species show no periodicity at site E10 but arrive seasonally at the MI site. There has been an increase in sulfate levels in recent years $(1973-80)$ at site E10 while nitrate levels have remained unchanged. This is suggestive of increased volcanism or increased transport of sulfate from crustal or volcanic sources.

\section{ACKNOWLEDGEMENTS}

The 1981-82 University of New Hampshire field party included P A Mayewski (leader), W B Lyons, B Allen III and P J Feuerbach. The authors acknowledge the support of US Navy Squadron VXE-6 for deployment in the field, C I Davidson (Carnegie-Mellon University) for supplying analytical time on the C-MU ion chromatograph, and T C Loder III (University of New Hampshire) and G J Larson (Michigan State University) for analytical advice and review of the manuscript. We are also grateful for the comments made on an earlier draft of this paper by an anonymous reviewer. This research was funded by NSF grants DPP-8203891 and DPP -8304801 .

\section{REFERENCES}

Aristarain A J, Delmas R J, Briat M 1982 Snow chemistry on James Ross Island (Antarctic Peninsula). Journal of Geophysical Research 87(C13): 11004-11012

Arkin H 1962 Table for statisticians. Second edition. New York, Barnes and Noble 
Boutron C, Martin S 1980 Sources of twelve trace metals in Antarctic snows determined by principal component analysis. Journal of Geophysical Research 85(C10): 5631-5638

Delmas R, Boutron C 1980 Are the past variations of the stratospheric sulfate burden recorded in central Antarctic snow and ice layers? Journal of Geophysical Research 86(C10): $5645-5649$

Delmas R, Briat M, Legrand M 1982 Chemistry of south polar snow. Journal of Geophysical Research 87(C6): 4314-4318

Dort W Jr 1968 Climatic causes of alpine glacier fluctuation, southern Victoria Land. International Association of Scientific Hydrology Publication 86 (ISAGE) 358-362

Dow J A S, Neall V E 1974 Geology of the lower Rennick Glacier, northern Victoria Land, Antarctica. New Zealand Journal of Geology and Geophysics 17(3): 659-714

Duphorn K 1981 Physiographical and glaciogeological observations in north Victoria Land, Antarctica. Geologisches Jahrbuch (Hannover), Reihe B 41: 89-109

Glibert P M, Loder T C 1977 Automated analysis of nutrients in sea water: a manual of techniques. Woods Hole, MA, Woods Hole Oceanographic Institute (Technical Report 77-47)

Herron M M 1982[a] Glaciochemical dating techniques. In Currie L A (ed) Nuclear and chemical dating techniques: interpreting the environmental record. Washington, DC, American Chemical Society: 303-318 (Symposium Series 176)

Herron M M 1982[b] Impurity sources of $\mathrm{F}^{-}, \mathrm{Cl}^{-}, \mathrm{NO}_{3}{ }^{-}$and $\mathrm{SO}_{4}{ }^{2-}$ in Greenland and Antarctic precipitation. Journal of Geophysical Research 87(C4): 3052-3060

Kelley J C 1976 Sampling the sea. In Cushing D H, Walsh $\mathrm{J} \mathrm{J}$ (eds) The ecology of the seas. Philadelphia, PA, W B Saunders: 361-387

Koopmans L H 1974 Spectral analysis of time series. New York, Academic Press

Kukla G, Gavin J 1981 Summer ice and carbon dioxide. Science 214(4520): 497-503

Kyle P, Palais J, Delmas R 1982 The volcanic record of Antarctic ice cores: preliminary results and potential for future investigations. Annals of Glaciology 3: 172-177

Lewis J E, Moore T R, Enright N J 1983 Spatial-temporal variations in snowfall chemistry in the Montreal region. Water, Air and Soil Pollution 20: 7-22

Mayewski P A, Lyons W B 1982 Source and climatic implication of the reactive iron and reactive silicate concentration found in a core from Meserve Glacier, Antarctica. Geophysical Research Letters 9(3): 190-192

Mayewski P A, Lyons W B, Ahmad N, Smith G, Pourchet M 1984 Interpretation of the chemical and physical time-series retrieved from Sentik Glacier, Ladakh Himalaya, India. Journal of Glaciology 30(104): 66-76

Radke L F 1982 Sulphur and sulphate from Mt Erebus. Nature 299(5885): 710-712

Stuart A W, Heine A J 1961 Glaciological work of the 1959-60 U.S. Victoria Land traverse. Journal of Glaciology 3(30): 997-1002

U S Navy 1981 Marine climatic atlas of the world. Vol $I X$. Washington, DC, US Naval Weather Service Command (NAVAIR Report 50-1C-65)

Van Epsen P, Adams F 1983 The application of principal component and factor analysis procedures to data for elemental concentrations in aerosols from a remote region. Analytica Chimica Acta 150: 153-161

Weyant W S 1967 The Antarctic atmosphere: climatology of the surface environment. New York, American Geographical Society (Antarctic Map Folio Series 8)

Zeller E J, Parker B C 1981 Nitrate ion in Antarctic firn as a marker for solar activity. Geophysical Rsearch Letters 8(8): 895-898 